\title{
O sensacionalista: uma mídia pelo método confuso
}

\author{
Rony Petterson Gomes do Vale ${ }^{\mathrm{i}}$ \\ Camila Cardoso Barros ${ }^{\text {ii }}$
}

\begin{abstract}
RESUMO
O presente artigo investiga o website Sensacionalista, com base em um corpus composto por dez manchetes, e suas relações interdiscursivas por meio dos pressupostos da Teoria Semiolinguística de Patrick Charaudeau, focalizada no Discurso Midiático (CHARAUDEAU, 2006a) e no Discurso Humorístico, conforme Vale (2013). O portal Sensacionalista apoia-se em suporte on-line e apresenta características de tradicionais mídias on-line, abordando conteúdos atuais. Julgando a pertinência social do tema, uma mídia que perpassa o uso do humor, na presente conjuntura sociopolítica brasileira e mundial, realizou-se, a partir de revisão de literatura da Teoria Semiolinguística e dos pressupostos de Vale (2013), a descrição e análise sociodiscursiva do corpus, considerando a possível relação de interdiscursividade entre os Discursos Midiático e Humorístico. Os resultados indicam o predomínio da visada de fazer-rir, tornando o Sensacionalista um representante do Discurso Humorístico.
\end{abstract}

Palavras-chave: Análise do Discurso; Teoria Semiolinguística; Sensacionalista.

\begin{abstract}
The article investigates the website Sensacionalista, based on a corpus of ten headlines, and its interdiscursive relationships through the theoretical framework of the Semiolinguistic Theory from Patrick Charaudeau, focused on Media Discourse (CHARAUDEAU, 2006a) and on Humorous Discourse, based on Vale (2013). The Sensacionalista website relies on online support and presents characteristics similar to traditional online media, approaching current contents. Considering its social
\end{abstract}

\footnotetext{
i Doutor em Linguística pela UFMG (2009-2013). Possui Graduação em Letras (Licenciatura em Português/Literatura) pela UFV (2008), Mestrado em Linguística pela UFMG (2009) e pós-doutorado pela UFMG (2017). Tem experiência na área de Letras, com ênfase em Linguística do Texto e do Discurso, atuando principalmente nas seguintes subáreas: Análise do Discurso, Gêneros do Discurso/Textual, Leitura e Produção Textual, Argumentação e Retórica. Desenvolve trabalhos de pesquisa observando a interface entre o riso, o risível (teorias e práticas) e o Discurso, a partir dos postulados da Análise do Discurso em diálogo com outras áreas do conhecimento como a Filosofia, a Retórica, a História, a Literatura, a Comunicação Social etc.

ORCID: http://orcid.org/0000-0002-0123-9828 | ronyvale@gmail.com

ii Mestranda em Estudos do Texto e do Discurso pela Universidade Federal de Viçosa, sob orientação do Prof $^{\circ}$ Dr. Rony Petterson Gomes do Vale. Possui graduação em Letras (Licenciatura em Português/Inglês) pela mesma universidade (2021). Foi bolsista de Iniciação Científica, com pesquisa em Linguística Cognitiva (PIBIC-SICOOB/UFVCredi). Atualmente, realiza pesquisas na área de Letras, com ênfase em Linguística do Texto e do Discurso, atuando principalmente na subárea da Análise do Discurso, com os Discursos Midiático e Humorístico.

E-mail: camila.c.barros@ufv.br
} 
pertinence, a media that uses humor, in the current Brazilian and global socio-political conjuncture, it was conducted, through a literature review of the Semiolinguistic Theory and the contributions of Vale (2013), a description and sociodiscursive corpus analysis, considering the possible interdiscursivity relationship between Media and Humorous Discourse. The results indicate the prevalence of the purpose of making people laugh, posing the Sensacionalista as a representative of Humorous Discourse.

Keywords: Discourse Analysis; Semiolinguistic Theory; Sensacionalista.

\section{INTRODUÇÃO}

O verdadeiro jornalista é como o batedor de cortejos: segue o itinerário traçado pela opinião pública, dando-se ares de que a está conduzindo. (MASUCCI, 1958, p. 138 - verbete "Jornalista")

Em tempos de crises e de divergências sociais e políticas crescentes, as mídias são essenciais no processo de disseminação do discurso de informação. Além disso, com o desenvolvimento da internet, as mídias de informação de molde tradicional adaptaram-se e, atualmente, o consumo de notícias acontece prioritariamente on-line, a partir de websites e redes sociais, e tem se expandido ${ }^{1}$. Nesse contexto, o portal Sensacionalista, fundado em 2009 e mantido exclusivamente em suporte on-line, encontra nas divergências políticas, ideológicas e sociais uma vasta fonte de temas para a "criação de notícias" entre aspas, pois, embora sua legitimidade aparentemente esteja até certo ponto garantida pelo fato de o Sensacionalista se apresentar de modo muito semelhante aos portais de notícias on-line (como, por exemplo, o R7, o G1, o Band.com, entre outros), provoca dúvidas em seus leitores quanto à credibilidade de suas notícias, devido à presença de elementos do âmbito do humor.

Tendo isso em vista, neste trabalho busca-se compreender como é a constituição do discurso do Sensacionalista, através dos pressupostos da Teoria Semiolinguística de Patrick Charaudeau e das considerações de Vale (2013) acerca do Discurso Humorístico. A justificativa para a escolha da temática - a análise da interdiscursividade do Discurso Midiático e do Discurso Humorístico no website perpassa a relevância social da compreensão do problema da propagação de notícias pelas mídias. Para tanto, ressalta-se que, no atual contexto sociopolítico, econômico e 
sanitário mundial e brasileiro, é importante que saibamos refletir sobre como as informações estão sendo disseminadas.

Diante disso, objetiva-se analisar, num corpus composto por manchetes (cf. anexo) do Sensacionalista: i) as características linguístico-discursivas do portal; ii) o contrato comunicacional proposto; iii) as visadas predominantes; e iv) a questão da incoerência e do humor. Isso de modo a comprovar nossa hipótese de que o Sensacionalista aparentemente atua como uma mídia que funciona pelo Método Confuso ${ }^{2}$.

De forma a alcançarmos esses objetivos, dividimos este trabalho em quatro seções, em que, primeiramente, discorremos sobre o portal Sensacionalista. Na seção seguinte, abordamos os pressupostos que nortearam nossas análises. Posteriormente, apresentamos as discussões e reflexões a partir da análise do corpus selecionado. Por fim, tecemos as considerações finais, evidenciando os resultados obtidos pelas discussões.

\section{O SENSACIONALISMO E O SENSACIONALISTA}

$\mathrm{Na}$ esfera jornalística, o sensacionalismo está relacionado ao jornalismo popular e é caracterizado, segundo Pedroso (2001, p. 52), como uma produção discursiva de informação, definida a partir de "critérios de intensificação e exagero gráfico, temático, linguístico e semântico, contendo em si valores e elementos desproporcionais, destacados, acrescentados no contexto de representação ou reprodução do real social". Em outros termos, sensacionalismo também pode ser definido como aquilo que provoca sensações. Tendo isso em mente, devemos ter cautela na análise do portal Sensacionalista e não tratá-lo como uma mídia comum. Lembremos: o Sensacionalista é um "jornal isento de verdade" 3

O portal, fundado em 2009 por Nelito Fernandes ${ }^{4}$ e atualmente vinculado ao Grupo Abril, mais especificamente à Revista Veja, ganhou repercussão mundial com a veiculação, em 2010, da manchete "Mulher engravidou vendo filme pornô 3D", que, com expressiva propagação, foi interpretada como verdadeira, levando a plataforma a se posicionar, reiterando a não veracidade do fato em uma nota adicionada ao final da notícia ${ }^{5}$. No Brasil, ao pensarmos na popularidade do website, pode-se dizer que ela 
aumentou consideravelmente durante as eleições de 2014 e durante o processo de impeachment da então presidenta Dilma Rouseff, em 2016. Por tratar de temas polêmicos, a plataforma foi processada, em 2015, pelo deputado federal Marco Feliciano, que alegou danos morais pelas publicações envolvendo seu nome, não obtendo, no entanto, sucesso com a ação judicial.

Atualmente, o Sensacionalista apresenta-se em sua versão website (foco deste trabalho) e também nas redes sociais Facebook, com aproximadamente 3,2 milhões de curtidas; Instagram, com mais de 600 mil seguidores; Twitter, acompanhado por mais de dois milhões de pessoas e Youtube, com o número aproximado de quatro milhões de visualizações. Em contexto off-line, o criador do portal e outros jornalistas publicaram o livro A História Sensacionalista do Brasil, que, por uma perspectiva aos moldes do website, isenta de verdade, narra a história do País. Além do livro, o sucesso do website deu origem à produção audiovisual de um telejornal fictício no canal Multishow, transmitido por cinco temporadas entre 2010 e 2013.

No que tange ao público consumidor, ou seja, quem habitualmente acessa os conteúdos produzidos, depreende-se, pela análise do Mídia Kit ${ }^{6}$, que o Sensacionalista é consumido, em maior parte, por pessoas bem informadas, que apresentam conhecimento prévio das temáticas abordadas, sendo, majoritariamente, pessoas de classe média, com faixa etária entre 18 e 34 anos. A necessidade do conhecimento prévio pode ser explicada pelo fato de o portal trabalhar com manchetes e notícias que fazem referências a fatos atuais do Brasil e do mundo, relacionados a acontecimentos sociais e políticos.

Com relação ao aspecto visual do Sensacionalista, constata-se, a priori, a escolha das cores, preto, branco e vermelho, utilizadas para o título (logomarca), semelhante, em aparência, ao do portal de notícias norte-americano The New York Times. Além dessa similaridade, é possível verificar que a estrutura e disposição das seções e dos conteúdos se aproximam expressivamente à de outros portais tradicionais brasileiros, como G1 e R7, com as notícias recentes presentes na página inicial e categorias na parte superior que visam ao agrupamento dos conteúdos publicados de acordo com a temática, a saber, no Sensacionalista: "Home", "Vídeos", "País", "Esporte", "Entretenimento", "Mundo", “Digital”, "Listas", “Comportamento" e "Camisetas". Cada notícia é associada a uma manchete que apresenta as principais 
informações do conteúdo abordado e uma imagem relacionada ao tema, característica também notável em outros portais jornalísticos.

Ademais, as escolhas lexicais e linguísticas nas manchetes/notícias e a predileção por textos curtos e objetivos são particularidades que o Sensacionalista compartilha com o jornalismo tradicional. No que concerne ao conteúdo, no entanto, a leitura das manchetes/notícias do portal demonstra que este se apresenta, por vezes, inverossímil e, em alguns momentos, ilógico; todavia, a construção de seus conteúdos permanece presa aos fatos verídicos.

O Sensacionalista, portanto, pode ser compreendido como uma plataforma de notícias de significativo alcance, o que é potencializado por suas redes sociais, devido ao expressivo número de usuários. Nesse sentido, Instagram, Facebook, Twitter e Youtube proporcionam o compartilhamento das notícias em maior escala, além de possibilitarem que os internautas interajam com as postagens por meio de comentários, curtidas e reações. A interação, vale mencionar, também é característica marcante do portal, uma vez que algumas notícias são construídas a partir de contribuições dos leitores, retiradas das redes sociais ${ }^{7}$.

A partir do exposto, pode-se dizer que o Sensacionalista compartilha características com os tradicionais portais jornalísticos, como estrutura e linguagem. No entanto, em relação aos conteúdos, percebe-se que não são verdadeiros e passíveis de verificação. Nesse sentido, é importante discorrer acerca da problemática das fake news, que no contexto atual alcançou dimensões de caráter político, emergindo o seu debate a partir das eleições norte-americanas em 2016, em que o caráter ficcional das notícias era camuflado ao extremo. Ramalho (2018) pontua que uma notícia falsa não é necessariamente fake news, se pelo conceito de fake news for compreendida a vinculação exclusiva de informações de teor político. Essa consideração é necessária na medida em que o Sensacionalista compartilha notícias não verdadeiras, isto é, com conteúdo que não condiz à realidade, mas, como é possível deduzir, não as produz no intuito de difamação.

\section{UM POUCO DE TEORIA}


Tendo em vista as considerações acerca do Sensacionalista, é preciso que, previamente à realização da análise do objeto de estudo, tracemos um breve percurso pelos pressupostos teóricos que orientam nosso trabalho, a saber: a Teoria Semiolinguística de Patrick Charaudeau. Assim, nas próximas subseções, abordaremos a questão da enunciação, as categorias do contrato de comunicação, as visadas discursivas e, por fim, o Discurso Midiático.

\subsection{O modo de organização enunciativo}

Nos modos de organização do discurso ${ }^{8}$ propostos por Charaudeau (2008), o conceito de enunciação é de suma importância, principalmente para a compreensão do modo de organização enunciativo. Conforme Charaudeau (2008, p. 81) explicita, o modo enunciativo é uma categoria de discurso que diz respeito ao modo como o sujeito falante age discursivamente no ato de comunicação. Nessa perspectiva, enunciar referese à organização das categorias da língua que indicam a posição ocupada pelo sujeito falante em relação ao seu interlocutor. Essa categorização possibilita identificar as três funções do enunciativo, a saber: o comportamento alocutivo, elocutivo e delocutivo.

O comportamento alocutivo é definido por Charaudeau (2008, p. 82) como a "relação de influência do locutor sobre o interlocutor". Na alocução, o sujeito falante pode se enunciar em posição de superioridade, impondo determinadas ações que estabelecem uma relação de força (como, por exemplo, na interpelação ou na injunção); ou em posição de inferioridade, em que ocorre uma "solicitação" ao interlocutor, instituindo uma relação de petição ou interrogação (demanda de informação).

No que concerne à relação do locutor consigo mesmo, verifica-se o comportamento elocutivo. Nesse comportamento, o sujeito falante enuncia seu ponto de vista sem que haja o envolvimento do interlocutor neste posicionamento. Segundo Charaudeau (2008, p. 83), esse ponto de vista pode ser especificado como modos: de saber, de avaliação, de motivação, de engajamento ou de decisão. Assim, o resultado dessa enunciação tem o efeito de modalizar subjetivamente a verdade e revelar a posição do sujeito falante frente ao que ele diz.

Por fim, o comportamento delocutivo apresenta-se como aquele que ocorre entre o sujeito falante e um terceiro (aqui no sentido de mundo). Esse comportamento é 
caracterizado por Charaudeau (2008, p. 83) pelo apagamento do sujeito falante (e também do interlocutor) no ato de enunciação, resultando em aparente objetividade, ou melhor dizendo, em um não vínculo entre o que se diz com aquele que diz ou que escuta. Nessa situação, são identificadas duas possibilidades: a) o propósito se impõe por si só, em que ocorre a asserção, e b) o propósito é um texto já produzido em que o sujeito falante atua como relator, sendo, portanto, o caso de discurso relatado.

Após as considerações acerca da enunciação e como esta é tomada no interdiscurso, caracterizaremos, na sequência, o contrato de comunicação a partir das relações entre os sujeitos no ato de linguagem e dos fatores que as regem.

\subsection{Do contrato de comunicação}

Charaudeau (2004, p. 131) considera que todo ato de linguagem demanda a coexistência dos sujeitos envolvidos em uma relação intersubjetiva e "a existência de convenções, de normas e de acordos que regulamentam a troca linguageira, a existência de saberes comuns que permitem que se estabeleça uma intercompreensão”. Nessa ótica, o contrato de comunicação corresponde ao conjunto de condições no qual um ato de comunicação se desenvolve, resultado, de acordo com Charaudeau (2006a), das características da situação de troca (dados externos) e das características discursivas (dados internos).

Os dados externos são agrupados por Charaudeau (2006a, p. 68-69) em quatro categorias que correspondem a condições, a saber: condição de identidade ("quem fala a quem?"), condição de finalidade (“estamos aqui para dizer o quê?”), condição de propósito (“do que se trata?”) e condição de dispositivo (“em que ambiente se inscreve?"). Nessa categorização, destacamos a condição de identidade, pois o reconhecimento dos sujeitos do discurso envolvidos na situação contribui para o entendimento do ato de comunicação. Nesse sentido, Charaudeau (2001) reconhece a existência de quatro sujeitos que se encontram em um espaço externo, nível do fazer, e em um espaço interno, no nível do dizer. No espaço externo, situam-se os seres sociais: o sujeito comunicante EUc, atuando como locutor; e o sujeito interpretante TUi, receptor, considerados os parceiros no ato de comunicação. No que concerne ao espaço interno, localizam-se os seres de palavras: o sujeito enunciador EUe, assumindo a 
enunciação, e o sujeito destinatário TUd, um receptor ideal projetado pelo EUc, considerados protagonistas no ato.

Quanto aos dados internos, Charaudeau (2006a) considera três espaços de comportamentos linguageiros: espaço de locução, espaço de relação e espaço de tematização, sendo esses os que constituem as restrições discursivas do ato de comunicação. Em suma, constata-se que os dados externos e internos que compõem o contrato de comunicação constituem, segundo Charaudeau (2004), as condições para que os sujeitos envolvidos no ato de comunicação possam interagir e co-construir o sentido.

Diante o exposto, verifica-se que determinados fatores regem o contrato de comunicação e influenciam as escolhas do sujeito falante. Com isso em mente, apresentamos, a seguir, as visadas discursivas, utilizadas de maneira a atender as intencionalidades desse sujeito.

\subsection{Das visadas discursivas}

Em uma situação de comunicação, as visadas discursivas atuam de maneira a atender a expectativa do sujeito falante no ato de linguagem e correspondem, de acordo com Charaudeau (2004), a uma intencionalidade psicossociodiscursiva projetada para um destinatário ideal, considerando que o sujeito falante não possui controle sobre os efeitos produzidos. Assim, com base nos elementos do contrato de comunicação, cabe ao sujeito falante selecionar quais visadas se adequam melhor ao seu projeto de fala.

Além das especificidades do contrato de comunicação, Charaudeau (2004, p. 23) pontua que um duplo critério define as visadas discursivas: "a intenção pragmática do EU em relação com a posição que ele ocupa como enunciador na relação de força que o liga ao TU; a posição que da mesma forma TU deve ocupar.”. Nessa perspectiva, a instância de recepção, "tu”, deve reconhecer as visadas como tais, pois é necessário que locutor e interlocutor recorram a elas (CHARAUDEAU, 2004). Com essa caracterização, Charaudeau (2004; 2006a) apresenta algumas das principais visadas, a saber: prescrição; solicitação; incitação; informação; instrução; demonstração; captação (ou pathos). 
Devido ao escopo de nosso trabalho, vamos nos ater às visadas de informação e de captação. No que concerne à visada de informação, ou de fazer-saber, Charaudeau (2004, p. 23) descreve que o "eu” encontra-se em posição de possuidor do saber, em que esse "eu" quer "fazer saber" e "tu" "dever saber". Em contrapartida, a visada de captação baseia-se no "fazer sentir", relacionada a apelos emocionais, podendo desdobrar-se em "fazer prazer", em que, segundo Lysardo-Dias (1998, p. 23), “a intencionalidade do ato comunicativo é atingir a sensibilidade do sujeito interpretante através da satisfação emocional e/ou através do lúdico". Considerando o nosso objeto como aparentemente desenvolvido no Discurso Midiático, apresentaremos como esse tipo de discurso pode ser caracterizado e como as visadas acima descritas agem no seu interior.

\subsection{Algumas particularidades do Discurso Midiático}

A produção do discurso articulado pelas mídias desenvolve-se a partir das condições socioeconômicas da máquina midiática e das condições semiológicas que interferem na realização do produto midiático e, nesse sentido, deve seguir um contrato de comunicação próprio do Discurso Midiático que regulariza as produções. Para a compreensão das especificidades desse discurso - restringindo-nos, aqui, a gêneros e situações de comunicação jornalísticas - é preciso abordar a identidade das instâncias de informação considerando a Instância de Produção e a Instância de Recepção, seguindo Charaudeau (2006a).

Ao considerarmos a Instância de Produção, verifica-se uma entidade compósita, na medida em que um discurso aparentemente uniforme atravessa vários atores e, dessa maneira, Charaudeau (2006a, p. 73) opta pela "designação 'instância midiática' à instância global de produção que integra os diferentes atores que contribuem para determinar a instância de enunciação discursiva”. E, nesse ponto, verifica-se a problemática das mídias, posto que, em muitos casos, não é realmente possível identificar quem responde pelo fato veiculado, isto é, quem produziu o discurso.

Com relação à Instância de Recepção, tem-se que esta é dotada de determinados valores sociais e éticos e, segundo Charaudeau (2006a, p. 78), ramifica-se 
em "destinatário-alvo" e "receptor-público". O primeiro é dividido entre alvo intelectivo, ao que é atribuída capacidade pensante; e alvo afetivo, diretamente relacionado ao aspecto emocional; já a opinião do público, pode-se dizer, é a integração entre ambos. Já o segundo, o "receptor-público", caracteriza-se como público de maneira geral, cabendo à mídia (re)conhecer suas opiniões e seus comportamentos.

É importante discorrer sobre a finalidade do contrato de comunicação midiático que, para Charaudeau (2008, p. 86), corresponde a um limiar entre duas visadas, caracterizadas previamente: a visada de informação, isto é, de fazer saber, que perpassa o desafio da credibilidade, e a visada de captação ou de fazer sentir, atravessando o desafio da dramatização e encontrando-se em uma lógica comercial, já que a mídia vêse na necessidade de informar ao cidadão, a partir de fatos verídicos, mas também de atingir o maior número de consumidores desse conteúdo.

Dessa maneira, percebe-se que as mídias devem manter a credibilidade, a veracidade e a coerência em seus discursos. No entanto, a coerência pode ser afetada em alguns aspectos, caso os planos isotópicos não se relacionem plenamente, conforme apresentamos a seguir.

\subsection{A questão da (in)coerência e do humor}

Com base em Charaudeau (2006b), podemos assumir que o plano isotópico de um dado texto diz respeito ao domínio temático, mais ou menos uniforme, ao qual o texto pertence; no entanto, esse plano isotópico pode ser alterado com o uso de palavras homônimas e polissêmicas que permitem passar de um isótopo de sentido a outro. Além dessas palavras, determinados discursos, como o literário e o humorístico, possibilitam a coexistência de planos isotópicos, o que pode instaurar diferentes tipos de incoerência.

Nesse ponto, Vale (2013, p. 278), ainda em conformidade com Charaudeau (2006b), apresenta três tipos de incoerências traduzidos no jogo semântico do humor, a saber: loufoquerie, insólita e paradoxal. A primeira incoerência, a loufoquerie, é aquela em que não há plano isotópico comum, isto é, os universos apresentados são completamente alheios aos outros. A segunda, a incoerência insólita, também lida com dois universos diferentes, mas, nesse caso, não são totalmente estranhos um ao outro. 
Por fim, a incoerência paradoxal lida com a relação entre duas lógicas no mesmo plano isotópico, mas contraditórias.

Com isso em mente, é possível, segundo Vale (2013), verificar a coocorrência de diferentes universos em determinados discursos, como o humorístico, nos quais a presença da incoerência pode acarretar determinados efeitos de sentido (por exemplo, a ironia ou o sarcasmo); noutros casos, ressalta-se que essa convivência pode acarretar incoerências; e, em alguns outros, as incoerências podem resultar na ilogicidade do texto. Nessas situações, é importante observar o planejamento (ou não) do uso de diferentes planos isotópicos e consequentes incoerências, isto é, se são aplicados com o intuito de atingir a finalidade do projeto de fala, como em um ato de comunicação humorístico, em que as incoerências visam, em sua maioria, ao fazer-sentir, por exemplo.

\section{ANALISANDO O SENSACIONALISTA}

O corpus de nosso trabalho, conforme abordado previamente, é composto por dez manchetes veiculadas entre 2015 e 2020 pelo Sensacionalista, obtidas no website do periódico. A seleção do corpus deu-se de maneira a abordar manchetes com temáticas diversas, abrangendo as seções País, Entretenimento, Mundo, Digital e Comportamento. Para realização da análise, apresentaremos, nas subseções seguintes, a encenação do gênero manchete e a encenação do ato de linguagem do portal. Além disso, é necessária uma compreensão aprofundada acerca do gênero e, posteriormente, sua descrição nos moldes de Charaudeau (2006a; 2008). Com essas informações, discute-se a questão da isotopia no portal e como esta afeta o gênero manchete, levando as finalidades a se deslocarem.

\subsection{Da encenação ao ato de linguagem no Sensacionalista}

Charaudeau (2001, p. 28) considera o ato de linguagem como um encontro entre o dizer e o fazer, em que o "fazer é o lugar da instância situacional que se autodefine pelo espaço que ocupam os responsáveis desse ato [...]" e o dizer "o lugar da instância discursiva que se define como uma encenação”. Indissociáveis, esses espaços 
compõem o circuito externo (do fazer) e o circuito interno (do dizer). Nessa perspectiva, o ato de linguagem torna-se um ato interenunciativo entre os sujeitos da linguagem e, segundo Charaudeau (2006a), todo ato de linguagem:

(i) vai nascer das circunstâncias de discurso específicas; (ii) vai se realizar no ponto de encontro dos processos de produção e de interpretação; (iii) será encenado por duas entidades, desdobradas em sujeito de fala e sujeito agente [EUc/EUe e TUd/TUi]. (CHARAUDEAU, 2008, p. 52)

No Sensacionalista, constata-se, no circuito externo do ato de linguagem, o EUc como os jornalistas e humoristas que integram a redação, sendo os responsáveis pela produção de conteúdos e veiculação de notícias. A identificação dessas pessoas não é divulgada no portal, mas, em notícia veiculada pelo jornal El País ${ }^{9}$, há a informação de que Nelito Fernandes, Martha Mendonça, Marcelo Zorzanelli, Leonardo Lanna, Bruno Machado e Rodolpho Rodrigo formam a equipe. Todos os integrantes são jornalistas ${ }^{10}$ e, dentre esses, o idealizador, Nelito Fernandes, apresenta-se, também, como humorista, já tendo atuado como redator do programa humorístico Casseta \& Planeta. Já o público interpretante, TUi, corresponde a qualquer indivíduo com acesso ao portal e que leia seu conteúdo. No circuito interno, o EUe representa a imagem de jornalistas de mídias tradicionais, e o TUd pode ser considerado, a priori, como composto por leitores de classe média, bem informados e com faixa etária entre 18 e $24 \operatorname{anos}^{11}$.

De forma a prosseguirmos com a discussão, caracterizaremos, na sequência, o gênero jornalístico manchete, com o objetivo de compreendermos as suas particularidades.

\subsection{Considerações gerais acerca do gênero "manchete"}

A princípio, apresentaremos algumas definições do gênero "manchete" para entendermos seus funcionamentos e particularidades. Vejamos o que nos diz Costa (2008) no seu Dicionário de Gêneros Textuais:

Geralmente é um enunciado breve, mas de grande força enunciativa, que chama (v. chamada) a atenção do leitor para o fato de maior destaque e até pode atrair o leitor para a leitura da matéria jornalística destacada. Como enunciado curto e objetivo, sintetiza com precisão a informação (v.) mais importante do texto e sempre procura expressar o aspecto mais específico do assunto, não o mais geral. Por essa característica fundamental, a 
manchete/título é uma espécie de link (v.) que o leitor tem para decidir se vai ler ou não o texto integral. (COSTA, 2008, p. 162)

Em perspectiva complementar à de Costa (2008), Guiraldelli e Sá (2012) apresentam que, no Manual de Redação e Estilo (2005) do jornal O Globo, a manchete é determinada como o ponto principal da notícia, concentrando o que é mais importante. Guiraldelli e Sá (2021) também expõem a definição do gênero que consta no Manual da Folha de São Paulo (1984, p. 58), em que a manchete "deve ser tensa, rápida, sintética, nervosa, objetiva. Deve ser dramática sem perder a sobriedade”. Com essas caracterizações, percebe-se que a manchete atua como um "cartão de apresentação", conforme estabelece Bertoque (2010, p. 68), sendo a responsável por motivar (ou não) o interesse no leitor para o conteúdo na íntegra. Diante disso, consideraremos que, no Discurso Midiático, as manchetes desempenham importante papel por despertarem o interesse na leitura completa da notícia e são definidas por características próprias, devendo veicular a informação principal de maneira clara, rápida e objetiva.

\subsubsection{A manchete no Sensacionalista pelo olhar da Teoria Semiolinguística}

Para a compreensão do funcionamento da manchete no portal, é necessário que analisemos o gênero com fundamento em categorias selecionadas da Teoria Semiolinguística, a saber: o contrato de comunicação, as visadas discursivas e os modos de organização do discurso (todavia, devido aos objetivos deste trabalho, nos ateremos somente à análise do modo enunciativo).

O contrato de comunicação, conforme explicita Charaudeau (2006a), corresponde às condições de realização da troca linguageira em que estão envolvidos os sujeitos, a partir das características da situação de troca. Consideremos a manchete a seguir:

\section{(1) CARIOCA CONSTRÓI SAUNA EM CASA PARA SE REFRESCAR NO VERÃO}

No que tange aos dados externos, categorizados por Charaudeau (2006a) em quatro condições, apresentamos, primeiramente, a condição de identidade discursiva, caracterizada por Charaudeau (2009) como construída pelo sujeito falante. Com efeito, 
atentando para os sujeitos do discurso presentes no circuito externo, temos o EUc como jornalistas e humoristas (expostos anteriormente), e o TUi, qualquer pessoa com acesso ao portal. Quanto ao circuito interno, temos o EUe sendo a projeção da imagem de jornalistas atuantes nas mídias tradicionais, e TUd, o público alvo do portal. Na manchete (1), com enunciado curto, objetivo e claro, a identidade do EUe não poderia corresponder à de um jornalista "sério", visto que o conteúdo da manchete é ilógico e não é passível de veracidade: uma sauna, em que a temperatura interna se aproxima dos $50^{\circ}$ Celsius, não poderia ser construída objetivando-se refrescância. Portanto, não deveria ser veiculado por um jornalista em sua atuação, já que esse, representando a instância de produção (CHARAUDEAU, 2006a), deve prezar, no Discurso Midiático, por informações verídicas e verificáveis, o que não ocorre no Sensacionalista.

No que concerne à condição de finalidade, espera-se no contrato midiático (cf. CHARAUDEAU, 2006a) a finalidade de informação, baseada na visada de fazer saber, que perpassa a questão da credibilidade e da veracidade. No entanto, como já verificado na condição de identidade, o conteúdo publicado pelo portal não apresenta indícios de que a finalidade seja informar fatos verdadeiros. Verifiquemos a manchete (2):

\section{(2) CIENTISTAS ENCONTRAM PROVAS IRREFUTÁVEIS DE QUE A TERRA É PLANA}

A constatação científica ${ }^{12}$ de que a terra é redonda data mais de 500 anos e é empiricamente impossível refutar tal fato, por mais que movimentos terraplanistas ${ }^{13}$ busquem "provar" o oposto. Assim, por essa manchete, vê-se que a finalidade não é fazer-saber e, portanto, a visada não é de informação.

A condição de propósito, referente ao "universo de discurso tematizado" (CHARAUDEAU, 2006a, p. 69), é variável no portal, visto que as temáticas abordadas são diversas, com seções referentes ao país (com enfoque na política brasileira), esportes, entretenimento, mundo, comportamento e digital. No entanto, pela análise das duas manchetes anteriores, percebe-se que são temas atuais e em discussão na sociedade, considerando a data de cada produção. É importante ressaltar que, para além de fatos atuais, o portal aborda, com frequência, episódios relacionados à política no Brasil, considerando que esses conteúdos "dão mais audiência”, nas palavras de Martha Mendonça ${ }^{14}$, uma das integrantes da equipe do website. 
A condição de dispositivo corresponde às condições materiais, considerando que "todo ato de comunicação se realiza num determinado ambiente físico que impõe restrições para a realização desse ato" (CHARAUDEAU, 2006a, p. 104). O Sensacionalista desenvolve-se em suporte on-line e as manchetes são veiculadas no website, que funciona como o canal de transmissão dos conteúdos e em circunstância escrita, monolocutiva, em que, segundo Charaudeau (2006a), não há intervenção explícita e nem presencial do interlocutor, devido à "ausência física entre as instâncias de troca" (CHARAUDEAU, 2006a, p. 113).

Após a caracterização do contrato de comunicação, iniciemos a discussão acerca do modo de organização enunciativo nas manchetes, conforme Charaudeau (2008). No corpus analisado, verificamos a dominância do ato delocutivo, o que pode ser explicado pelo fato de esse comportamento, que pode ocorrer por meio da asserção ou discurso relatado, propiciar, segundo Charaudeau (2008, p. 83), uma "enunciação aparentemente objetiva (no sentido de 'desvinculada da subjetividade do locutor')", o que permite ao enunciador certa neutralidade e "afastamento" do que é dito, conforme se verifica na manchete (3), a seguir:

\section{(3) LADY GAGA E BRADLEY COOPER SÃO FLAGRADOS EMBARCANDO PARA NORONHA}

Em (3), o enunciado faz referência aos rumores de um possível envolvimento entre Lady Gaga e Bradley Cooper após as gravações do filme "Nasce uma estrela" e relaciona o episódio dos atores norte-americanos com as "fofocas" ${ }^{15}$ sobre a ilha de Fernando de Noronha envolvendo artistas brasileiros em possíveis escândalos sexuais. $\mathrm{Na}$ manchete, percebe-se que o locutor afirma o acontecimento sem se posicionar e sem expor quem (e como) teria (aparentemente) flagrado os atores. Nessa manchete, percebe-se uma aparente construção objetiva do mundo, explicitada por Charaudeau (2008, p. 120) como constituída por uma "visão de verdade", com traços que possam ser verificados por outros sujeitos. No entanto, isso não ocorre, visto que o Sensacionalista não apresenta "provas" do ocorrido, como informações mais detalhadas sobre horário e local exatos ou de registros fotográficos do momento, além do fato de, na época das especulações sobre o envolvimento, Lady Gaga e Bradley Cooper negarem o fato, sendo o ator casado naquele período. 


\subsection{A questão da isotopia: por que o "não sério" no portal Sensacionalista?}

A investigação feita nos possibilitou averiguar que as manchetes no Sensacionalista versam sobre temáticas atuais, mas não verídicas. Com isso, é importante perceber como essa abordagem é realizada a partir dos conceitos de incoerência apresentados por Vale (2013, p. 277) ancorado em Charaudeau (2006b) quanto às isotopias (universos de leitura), a saber: loufoquerie; insólita; e paradoxal. Para discutir os tipos de incoerência no portal, tomemos como exemplo a manchete (4):

\section{(4) COM EPIDEMIA E VULCÕES, JESUS ANUNCIA VOLTA EM LIVE!}

O enunciado em (4) aborda três eventos relacionados ao ano de 2020: o contexto de disseminação da COVID-19, o isolamento social (que propiciou a expansão do fenômeno das "lives") e a ocorrência de desastres naturais. A informação do retorno de Jesus Cristo anunciado em uma live pode ser compreendida como um exemplo de incoerência paradoxal a partir de duas isotopias: 1) Jesus voltará quando epidemias e vulcões acontecerem e 2) Jesus anuncia seu retorno em live. É importante ressaltar que essa relação se estabelece ao considerarmos que eventos como pandemias e tragédias naturais são, nos textos bíblicos, como em Mateus 24: 6-8, os primeiros sinais ${ }^{16}$ de que Jesus retornaria. Além desse exemplo, no corpus, observou-se a recorrência de outros exemplos da incoerência paradoxal e também da insólita, a ser discutida a partir da manchete (5):

\section{(5) BRASILEIRO VIVE HOJE SUA 256ª SEXTA-FEIRA 13 DE 2019}

A manchete (5) foi publicada no dia 13/09/2019, 256 semanas após a eleição em que Bolsonaro tornou-se presidente. Dessa maneira, relaciona duas isotopias: 1) a ideia popular de que sextas-feiras 13 carregam uma atmosfera de negatividade, terror e má sorte e 2) a atuação do governo Bolsonaro. Desse modo, percebe-se que os dois planos isotópicos são distintos ("misticismo" popular e política), mas não completamente estranhos, ao considerarmos a ideia de que no primeiro ano de governo 
houve a repercussão de ações negativas que culminaram em crise no país e em ameaças a questões democráticas, sociais e ambientais.

No corpus analisado, não foi verificado nenhum exemplo de incoerência do tipo loufoquerie, o que nos permite depreender que, mesmo ao abordar conteúdos insensatos e ilógicos, as manchetes, em sua maioria, trabalham com universos de alguma maneira relacionados entre si - como verificado a partir das incoerências insólita e paradoxal.

Dessa forma, é possível compreender que a isotopia de diferentes planos no portal permite que a sua finalidade, a priori baseada na visada de fazer-saber, seja identificada como outra finalidade, baseada em uma visada de pathos que consistiria em fazer-sentir e, nesse caso, mais propriamente, em fazer-rir, deslocando o discurso para o não sério.

\section{CONSIDERAÇÕES FINAIS}

Neste artigo, buscamos compreender alguns efeitos de sentindo presentes nas manchetes do Sensacionalista pelo viés da Teoria Semiolinguística, enquadrando-o, a princípio, como representante do Discurso Midiático. Essa hipótese se embasou no fato de que o portal compartilha diversas características das tradicionais mídias, como, por exemplo, layout e disposição das categorias, podendo ele corresponder a um gênero desse tipo de discurso. Não obstante, no decorrer das análises, percebemos, no Sensacionalista, o rompimento de certas restrições impostas pelo Discurso Midiático. Essa(s) transgressão(ões) ocorre(m) ao considerarmos os conteúdos veiculados, visto que eles não condizem com informações verdadeiras e suscetíveis de verificação, o que viola a finalidade do contrato de comunicação midiático, que perpassa a visada de fazer saber, isto é, a finalidade de informação, relacionada à verdade, "a qual supõe que o mundo tem uma existência em si e seja reportado com seriedade numa cena de significação credível” (CHARAUDEAU, 2006b, p. 87).

Diante o exposto, ao perscrutar o corpus selecionado, constatou-se que a finalidade do portal se baseia mais em uma visada de pathos, ou fazer sentir, que consiste em, segundo Charaudeau (2008, p. 69), despertar no interlocutor um "estado emocional agradável ou desagradável”. Com essa elucidação, destaca-se a visada do 
portal em provocar essa sensação, mas também o deslocamento para o não sério, que ocasionaria, então, a predominância de outra visada: fazer rir.

Nessa perspectiva, Vale (2013, p. 160) pontua que o discurso não sério opõe-se ao discurso sério: o segundo marcado por sua autoridade adquirida através do discurso, e o primeiro, por uma espécie de "argumento de autoridade pelo avesso". O não sério é exemplificado por Vale (2013, p. 160) a partir do discurso do bobo da corte, que não deve ser levado a sério, por ele ser "só um bobo": ele "diz sem dizer ao mesmo tempo em que diz o que é preciso dizer". Assim, ao traçarmos um paralelo entre o discurso do bobo da corte com o discurso do Sensacionalista (considerando-se os devidos contextos e proporções), depreende-se que os conteúdos transmitidos pelo portal não devem também ser considerados como verdadeiros, isto é, levados a sério por seu público, visto que a visada do Sensacionalista se aproxima do (ou tende para) fazer-rir. Com base nisso, podemos dizer, assim como Vale (2013, p. 84), que a visada de fazer rir pode estar relacionada ao "divertimento e à busca pelo prazer" e, logo, ser depreendida no Discurso Humorístico, que pode "mobilizar qualquer gênero de discurso para elaborar suas cenografias" (MAINGUENEAU, 2010a, p.108 apud VALE, 2013, p. $138)$.

Dessa forma, a manifestação desse tipo de discurso no Sensacionalista pode ser identificada como uma característica do mutualismo oportunista que, segundo Vale (2013, p. 151), corresponde à "absorção e (re)utilização, ao mesmo tempo, da substância e da forma" de outro discurso, mantendo, portanto, relações interdiscursivas em um "convívio mais ou menos pacífico". Aliado ao conceito de mutualismo oportunista, Vale (2013, p. 152) pontua que a aparente ausência de estrutura tipológica no Discurso Humorístico propicia a este, além de absorver e re(utilizar) substância e forma, também "replicar uma gama de propriedades estruturais relativas às cenas de enunciação", concedendo ao Discurso Humorístico outra capacidade, a de replicação.

Ao considerarmos o Sensacionalista, identificamos a presença de tais características, mutualismo oportunista e replicação, tendo em vista que, conforme expõe Vale (2013, p. 204), o Discurso Humorístico convive em "relativa dependência com outros discursos" (no portal, com o Discurso Midiático) e replica "não somente os gêneros e os textos produzidos em outros tipos de discurso, mas também os dispositivos desses discursos" (há a replicação da estrutura dos gêneros midiáticos, como manchetes 
e notícias, e do dispositivo, com a similitude aos portais on-line de mídias tradicionais). À vista disso, constata-se que as condições assinaladas por esses dois conceitos (mutualismo oportunista e replicação) são satisfeitas e, dessa maneira, podemos depreender que o papel do humor é estruturante no Sensacionalista.

Já a "confusão" discursiva proposta pelo portal pode ser refletida a partir do conceito de Método Confuso (visto anteriormente, aqui, na página 2, nota ii) e a conceituação de Marketing pelo Método Confuso (doravante, MMC). Vale (2013, p 250) considera que, no MMC, "o humorista [...] encontra, na 'guerra' entre as empresas e suas marcas, espaço para fazer humor e, ao mesmo tempo, para ganhar dinheiro", como se verifica em vários sketches humorísticos do canal Portas dos Fundos. Por abordar situações cotidianas por uma perspectiva bem humorada, a "ridicularização" de certas empresas, como no episódio "Na lata"17", surge como uma "fórmula de marketing - confuso - que as empresas e as corporações veem como um novo espaço (humorístico cibernético) para divulgação de suas marcas" (VALE, 2013, p. 252): todas as marcas são atacadas, ridicularizadas, seus defeitos apontados, seus clientes taxados conforme a renda social, não há interesse na promoção mas na desconstrução da marca em prol da zombaria; no entanto e mesmo assim, há promoção - confuso? sim... método confuso!

Com fundamento no supracitado, podemos, por analogia, enquadrar o Sensacionalista como uma Mídia pelo Método Confuso, considerando que o portal se desenvolve a partir da forma e do conteúdo do Discurso Midiático, mas possui o humor como fator estruturante. Logo, embora o Sensacionalista informe (uma vez que o relato, por vezes, está relacionado a fatos), o humor não se apresenta como estratégia: não é o humor atravessando o Discurso Midiático; mas o Discurso Midiático servindo de estratégia de vinculação do Discurso Humorístico.

\section{Referências}

BERTOQUE, L. A. D. P. A funcionalidade de construções de voz em títulos de notícia e em manchetes de jornais impressos. 2010. 205f. p. 67-69. Dissertação (Mestrado em Letras) - Faculdade de Letras da Universidade Federal de Goiás, Goiânia.

BUSATTO, L. Posfácio: M. F. e sua gramática. In: FRADIQUE, M. Grammatica portugueza pelo methodo confuso: adoptado em todas as escolas primarias, secundarias e terciarias do Brasil e suburbios. 3 ed. Rio de Janeiro: Rocco, 1984, p. 273-274. 
CHARAUDEAU, P. Discurso das Mídias. São Paulo: Contexto, 2006a.

CHARAUDEAU, P. Des catégories pour l'humour. Questions de communication: humor et média. Définitions, genres et cultures. Nancy: Presses Universitaires de Nancy, n. 10. 2006b, p. 27-43.

CHARAUDEAU, P. Identidade social e identidade discursiva, o fundamento da competência comunicacional. In: PIETROLUONGO, M. (Org.). O trabalho da tradução. Rio de Janeiro: Contra Capa, 2009, p. 309-326.

CHARAUDEAU, P. Linguagem e discurso: modos de organização. São Paulo: Contexto, 2008.

CHARAUDEAU, P. Uma teoria dos sujeitos da linguagem. In: MARI, H.; MACHADO, I. L; MELLO, R. (Org.) Análise do Discurso: fundamentos e práticas. Belo Horizonte: NAD/FALE/UFMG, 2001. Cap. 1, p. 23-37.

CHARAUDEAU, P. Visadas discursivas, gêneros situacionais e construção textual. In: MACHADO, I. L.; MELLO, R. (Org.) Gêneros: Reflexões em análise do discurso. Belo Horizonte: NAD/FALE/UFMG, 2004. Cap.1, p. 13-42.

COSTA, S. R. Dicionário de gêneros textuais. 3 ed. Belo Horizonte: Autêntica Editora, 2014, p. 19-31.

FRADIQUE, M. A lógica do Absurdo. Rio de Janeiro: Editora Leite Ribeiro, 1925.

FRADIQUE, M. Grammatica portugueza pelo methodo confuso: adoptado em todas as escolas primarias, secundarias e terciarias do Brasil e suburbios. 3 ed. Rio de Janeiro: Rocco, 1984.

GUIRALDELLI, L. A.; PEREIRA DE SÁ, M.C. Estudando os efeitos da ambiguidade no discurso jornalístico manchete. Entrepalavras, Fortaleza, v. 4, n. 1, p. 82-98, mai. 2014.

LUSTOSA, I. Brasil pelo método confuso: humor e boemia em Mendes Fradique. Rio de Janeiro: Bertrand Brasil, 1993.

LYSARDO-DIAS, D. O saber-fazer comunicativo. In: MACHADO, I. L.; CRUZ, A. R. LYSARDO-DIAS, D. (Org.) Teorias e práticas discursivas: estudos em análise do discurso. Belo Horizonte: Carol Borges, 1998. Cap. 1, p. 17-24.

MASUCCI, F. Dicionário humorístico. 2 ed. São Paulo: Editora Leya, 1958.

PEDROSO, R. N. A construção do discurso de sedução em um jornal Sensacionalista. São Paulo: Annablume, 2001. Cap. 2, p. 50-52. 
RAMALHO, W. O combate às fake news no Brasil: um estudo sobre a checagem de fatos. 2018. 71f. Monografia (TCC) - Fundação Getúlio Vargas, Rio de Janeiro.

VALE, R. P. G. O discurso humorístico: um percurso de análise pela linguagem do riso. 2013. 279f. Tese (doutorado) - Faculdade de Letras, POSLIN, UFMG, Belo Horizonte.

\section{Anexo}

Observação: todas as manchetes do corpus foram acessadas em 28 de outubro de 2020.

\section{COM EPIDEMIA E VULCÕES, JESUS ANUNCIA VOLTA EM LIVE}

Disponível em: https://www.Sensacionalista.com.br/2020/04/11/com-epidemia-evulcoes-jesus-anuncia-volta-em-live/

\section{CIENTISTAS ENCONTRAM PROVAS IRREFUTÁVEIS DE QUE A TERRA É PLANA}

Disponível em: https://www.Sensacionalista.com.br/2019/04/01/cientistas-encontramprovas-irrefutaveis-de-que-a-terra-e-plana/

3. BRASILEIRO VIVE HOJE SUA 256ª SEXTA-FEIRA 13 DE 2019

Disponível em: https://www.Sensacionalista.com.br/2019/09/13/brasileiro-vive-hojesua-256a-sexta-feira-13-de-2019/

4. LEI GARANTE DIREITO DE CHEGAR ATRASADO NO TRABALHO PARA QUEM ASSISTIU À FINAL DO MASTERCHEF

Disponível em: https://www.Sensacionalista.com.br/2017/08/23/lei-garante-direito-dechegar-atrasado-no-trabalho-para-quem-assistiu-a-final-do-masterchef/

\section{LADY GAGA E BRADLEy COOPER SÃO FLAGRADOS EMBARCANDO PARA NORONHA}

Disponível em: https://www.Sensacionalista.com.br/2019/02/25/lady-gaga-e-bradleycooper-sao-flagrados-embarcando-pra-noronha/

\section{BARES DO LEBLON REGISTRAM PICO DA CURVA DE ESTUPIDEZ}

Disponível em: https://www.Sensacionalista.com.br/2020/07/03/bares-do-leblonregistram-pico-da-curva-da-estupidez/

7. APÓS LEGALIZAÇÃO DA MACONHA NO MÉXICO, AMERICANOS SÃO PRESOS TENTANDO ATRAVESSAR A FRONTEIRA

Disponível em: https//www.Sensacionalista.com.br/2015/11/05/apos-legalizacao-damaconha-no-mexico-americanos-sao-presos-tentando-atravessar-fronteira/

8. JULGAR QUE ALGUÉm É POBRE PELA COR DE SUA PELE NÃO É RACISMO, DIZ A PESSOA QUE FOI RACISTA

Disponível em: https://www.Sensacionalista.com.br/2020/02/07/julgar-que-alguem-epobre-pela-cor-de-sua-pele-nao-e-racismo-diz-pessoa-que-foi-racista/

\section{CARIOCA CONSTRÓI SAUNA EM CASA PARA SE REFRESCAR NO VERÃO}

Disponível em: https://www.Sensacionalista.com.br/2020/01/12/carioca-constroi-saunaem-casa-para-se-refrescar-no-verao/ 


\section{APP QUE ENVELHECE USUÁRIO ATÉ A IDADE DE SE APOSENTAR FAZ SUCESSO}

Disponível em: https://www.Sensacionalista.com.br/2019/07/14/app-que-envelheceusuario-ate-a-idade-de-se-aposentar-faz-sucesso/

Recebido em: 18/12/2020

Aceito em: 09/03/2021

1 Informações disponíveis em: < https://portaldacomunicacao.com.br/2017/01/voce-sabe-como-obrasileiro-se-informa/> Acesso em 08 nov.2020.

${ }^{2}$ De acordo com Vale (2013), o Método Confuso é uma característica marcante das obras de Mendes Fradique que faz refletir, crítica, satírica e humoristicamente, sobre os diversos problemas da nação brasileira, invadindo "o espaço editorial através de informações falsas ou de deslocamentos de fatos, datas, personagens, biografias, notas de rodapé, prefácios etc.” (LUSTOSA, 1993, p. 113-114). Esse método, de acordo com o próprio Fradique (1984, p. 5), tem suas origens no modo a que se procedeu a publicação póstuma da obra do escritor Luís Delfino, feita por seu filho, Thomaz Delfino. Segundo Busatto (1984, p. 274), o fato de essa publicação ter se dado de modo disperso, em vários volumes, e sem uma ordem ou um critério, impossibilitou o acompanhamento da evolução estética da obra de Luís Delfino. Fradique ainda caracteriza o método como uma espécie de cruz ou calvário que marcaria sua produção textual posterior. De acordo com esse autor, ele "não tinha mais sequer o direito de errar", pois o leitor, indulgente, acreditou no método e aceitou a blage. "Resultado: não posso hoje [1925] traçar uma linha, por mais austero que pretenda ser, sem que venham com essa coisa fatal: Boa piada, método confuso" (FRADIQUE, 1925, p. 81). Como exemplo de obras de Fradique que seguem esse método podemos citar: História do Brasil pelo método confuso (1920); Feira livre: antologia das letras nacionais pelo método confuso (1923); e Grammatica portugueza pelo methodo confuso (1927).

${ }^{3}$ Disponível em: <https://www.sensacionalista.com.br/> Acesso em: 14 dez. 2020.

${ }^{4}$ Nelito Fernandes é jornalista e humorista. Atuou como redator no programa Casseta \& Planeta da Rede Globo e foi jornalista da Revista Época. Informações disponíveis em <https://epoca.globo.com/vida/noticia/2016/04/com-humor-que-nao-toma-partido-sensacionalista-virafenomeno-nas-redes-sociais.html> Acesso em: 29 set. 2020.

5 Disponível em: <https://www.sensacionalista.com.br/2010/05/04/mulher-engravidou-vendo-filmeporno-3d/> Acesso em: 29 set. 2020 
6 Apresentação comercial de um website ou blog com o objetivo de apresentar a plataforma, suas características principais e o público. As informações encontram-se no Mídia Kit - Sensacionalista disponível em <www.sensacionalista.com.br> Acesso em: 29 set. 2020.

${ }^{7}$ Exemplo de notícia colaborativa veiculada pelo Sensacionalista: "12 sugestões de novos nomes para o PT dadas pelos nossos leitores". Disponível em: <https://www.sensacionalista.com.br/2016/10/07/12novos-nomes-para-o-pt-sugeridos-por-nossos-leitores/> Acesso em: 30 set. 2020.

8 De Charaudeau (2006, p. 337-338), os modos de organização do discurso são “o conjunto dos procedimentos de colocação em cena do ato de comunicação, que correspondem a algumas finalidades (descrever, narrar, argumenta...)". Daí os quatro modos de organização do discurso: enunciativo, narrativo, descritivo e argumentativo que organizam a matéria semiolinguística (e mais especificamente, as categorias de língua) voltada para a realização dessas finalidades.

${ }^{9}$ Disponível em: <https://brasil.elpais.com/brasil/2016/06/24/politica/1466797534_968435.html> Acesso em: 15 out. 2020 .

${ }^{10}$ Como pontuado, todos os integrantes da equipe do portal são jornalistas. No entanto, ressaltemos as especificidades na formação de cada um, para além do jornalismo: Nelito Fernandes é humorista, roteirista e o idealizador do portal; Martha Mendonça é escritora, roteirista e dramaturga; Marcelo Zorzanelli é criador e roteirista; Leonardo Lanna é roteirista e redator; Bruno Machado é redator e Rodolpho Rodrigo é roteirista e screen writer.

11 Informações retiradas do "Mídia Kit" disponibilizado pelo Sensacionalista. Disponível em: < https://www.sensacionalista.com.br/midia-kit/> Acesso em: 19 mar. 2020.

12 Disponível em: <https://g1.globo.com/fantastico/noticia/2019/09/15/constatacao-de-que-a-terra-eredonda-completa-50-anos-este-mes.ghtml> Acesso em: 28 out. 2020.

${ }^{13}$ Disponível em: < https://super.abril.com.br/ciencia/a-ciencia-da-terra-plana/> Acesso em: 28 out. 2020. 14 Informações disponíveis em: < https://brasil.elpais.com/brasil/2016/06/24/politica/ 1466797534_968435.html> Acesso em 07 nov. 2020.

15 Informações disponíveis em: < https://catracalivre.com.br/dimenstein/folha-fofoca-do-surubao-deartistas-globais-vai-para-a-justica/> Acesso em: 07 nov. 2020.

16 “O primeiro sinal do retorno do Senhor: terremotos, fomes, pestes e guerras. Em Mateus 24:6 - 8: 'E ouvireis falar de guerras e rumores de guerras; olhai não vos perturbeis; porque forçoso é que assim aconteça; mas ainda não é o fim. Porquanto se levantará nação contra nação, e reino contra reino; e haverá fomes e terremotos em vários lugares. Mas todas essas coisas são o princípio das dores'”. Disponível em: <https://pt.bible-jp.org/sinais-da-volta-de-Jesus.html> Acesso em: 07 nov. 2020.

${ }^{17}$ Disponível em: <https://www.youtube.com/watch?v=NZb0XKHgtjo> Acesso em: 12 nov.2020. 